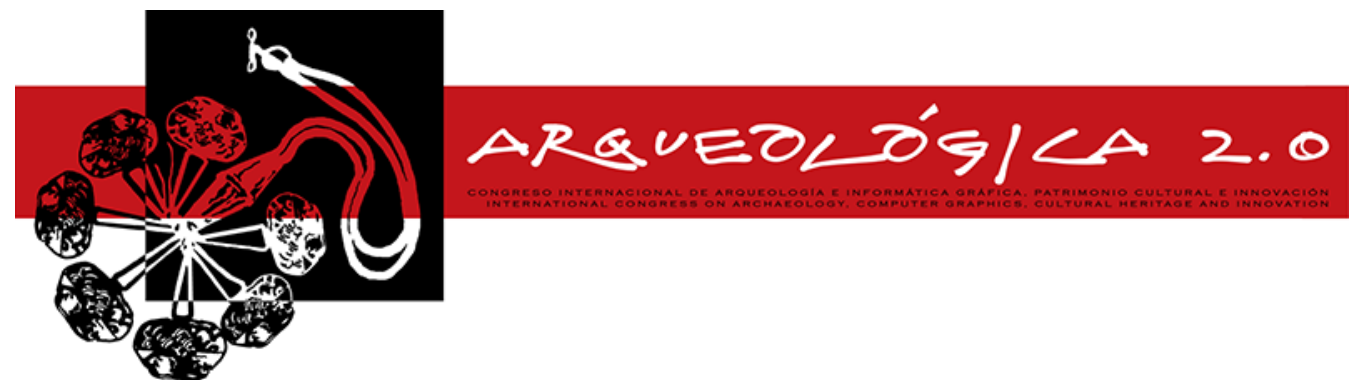

Proceedings of the $8^{\text {th }}$ International Congress

on Archaeology,

Computer Graphics,

Cultural Heritage and Innovation

'ARQUEOLÓGICA 2.0'

in Valencia (Spain),

Sept. $5-7,2016$

DOI: http://dx.doi.org/10.4995/arqueologica8.2016.4175

Received: $15 / 04 / 2016$

Accepted: 16/05/2016

\title{
VIRTUAL RECONSTRUCTION APPLIED TO THE RECOVERY AND HERITAGE DISCLOSURE OF THE OLD VILLAGE OF BELCHITE
}

\section{RECONSTRUCCIÓN VIRTUAL APLICADA A LA RECUPERACIÓN Y DIVULGACIÓN DEL PATRIMONIO DEL VIEJO BELCHITE}

\author{
Ana Alfaro ${ }^{\mathrm{a},{ }^{,}, \text {María Pilar Biel }^{\mathrm{b}} \text {, Diego Gutiérrez }}{ }^{\mathrm{c}}$ \\ ${ }^{a}$ Escuela de Ingeniería y Arquitectura, Universidad de Zaragoza, España. ana.alfaro.ro@gmail.com \\ ${ }^{\mathrm{b}}$ Departamento de Historia del Arte, Universidad de Zaragoza, España. pbiel@unizar.es \\ ${ }^{c}$ Instituto de Investigación en Ingeniería de Aragón, Universidad de Zaragoza, España. diegog@unizar.es
}

\begin{abstract}
:
Virtual reconstruction allows recovering missing heritage whilst becoming a useful tool for documenting and disseminating, when physical reconstruction is non-viable. This article explains the application of new technologies of virtual reconstruction (modelling and photogrammetry) to the recovery of the historic-artistic heritage of the Old Village of Belchite, specifically applied to the case of the San Augustin's Convent. This village was a battle scene in the Spanish Civil War in 1937 which has been abandoned since 1964. These days, it presents a state of ruin that increases exponentially over the time.
\end{abstract}

Key words: Old village of Belchite, arquitectonic 3D reconstruction, historic artistic heritage, photogrammetry, 3D model

\section{Resumen:}

La reconstrucción virtual permite recuperar entidades patrimoniales desaparecidas convirtiéndose en una útil herramienta de documentación y divulgación de las mismas cuando la reconstrucción física es inviable. El presente artículo trata sobre la aplicación de tecnologías de reconstrucción virtual (modelado y fotogrametría) a la recuperación del patrimonio histórico artístico del Pueblo Viejo de Belchite, en concreto aplicadas al caso del Convento de San Agustín. Esta localidad fue escenario de una batalla de la Guerra Civil Española en 1937 y lleva abandonada desde el año 1964. En la actualidad presenta un estado de ruina que aumenta exponencialmente con el tiempo.

Palabras clave: Pueblo Viejo de Belchite, reconstrucción arquitectónica 3D, patrimonio histórico artístico, fotogrametría, modelado 3D

\section{Introduction}

The old Belchite is a desolated village located in the district Campo de Belchite, in the province of Zaragoza (North East of Spain). Its narrow streets with dilapidated houses and empty yards make a great impact on people who visit it. Feeling that increases when its current state is compared with old photographs (from the first half of the twentieth century) in which people can appreciate the architectural wealth it had, and their streets full of life. These days most of its buildings have collapsed, and only some houses and religious buildings are preserved, but all in a very poor state. For this reason, virtual reconstruction has been considered as a useful tool to bring the viewer or visitor to a previous era (Gutierrez et al. 2004; Gutierrez et al. 2008; Fiamminghi et al. 2008; Scaglioni 2014; Balawat 2015; Peripimeno and Strufaldi 2015) when the village was inhabited and its houses were in perfect condition, and in this way, contribute to recovering the artistic heritage that has been lost.

This project has been focused on the making of a video showing the reconstruction of the Convent of San Agustin by modelling and photogrammetry techniques. This point has been chosen for its high architectural value being a representative example of monastic architecture of the 15th -17 th centuries. In relation with the techniques that has been used, modelling allows you to digitally reproduce the reconstructing of the missing parts of the building while photogrammetry allows you to reproduce the exact state of the ruins with a high level of accuracy. All of this to generate a video featuring its

`Corresponding Author: Ana Alfaro, ana.alfaro.ro@gmail.com 
virtual reconstruction, and its evolution over the time, in order to raise awareness of the importance of heritage legacy left to us (Fiamminghi et al. 2008; Laboratoire MAP du CNR 2014; Peripimeno and Strufaldi 2015).

\section{The Old Belchite}

Belchite is a village located $50 \mathrm{~km}$ South East of Zaragoza. In the past it was an important town with great architectural richness, characteristic of the area "el Bajo Aragón". Among its most representative buildings you can appreciate styles such as Mudejar, Renaissance, Baroque and neoclassical, both in civil and religious architecture (Vidal 2014; Baquero 1988; Cinca et al. 2008).

The Battle of Belchite (in 1937) was a Republican Army offensive during the Spanish Civil War in an effort to recover the northern side of the country. Once the war was finished, the village had significant damages, but even though it had a chance to recover (Fig. 1), the government of the francoist dictatorship decided Belchite should be abandoned to become a monument of exaltation of this regime. The result was the construction of a new village (Fig. 2) which was inaugurated in 1954, although the population did not abandon the former village until 1964 (Vidal 2014; Baquero 1988; Cinca et al. 2008).

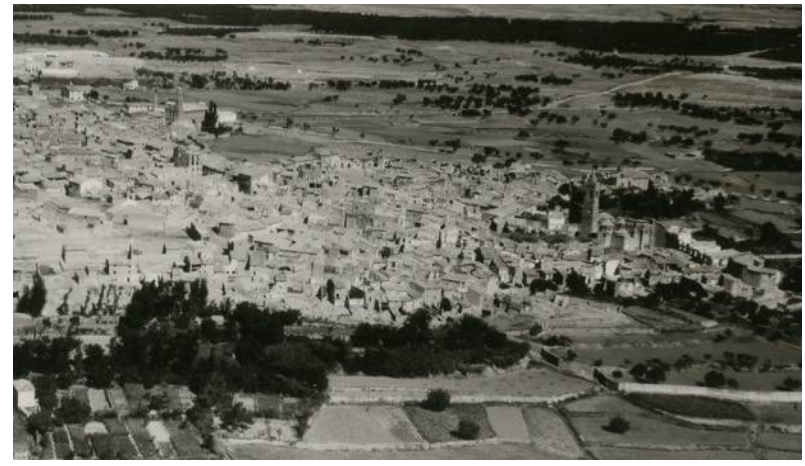

Figure 1: Aerial view of the old Village after the war (40s) in which most houses are still standing. (General Administration Archive).

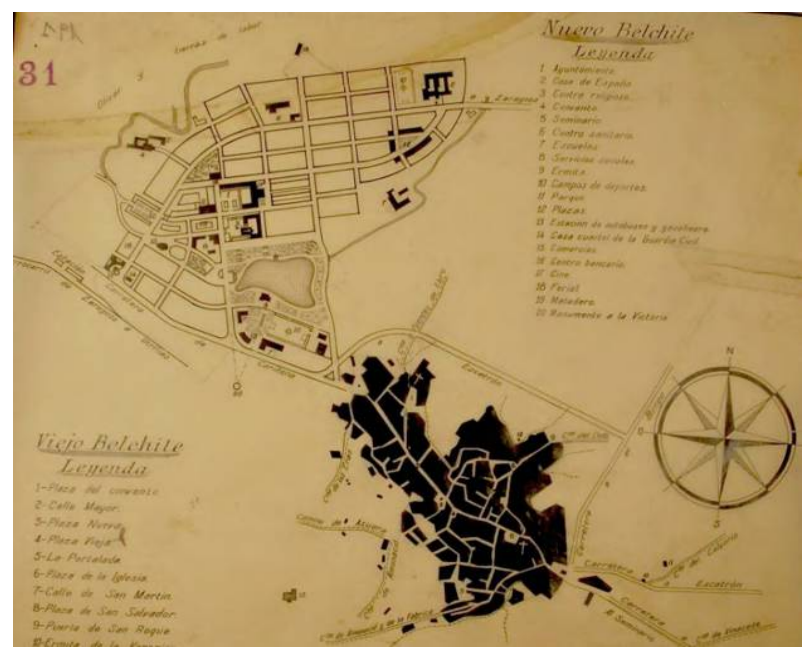

Figure 2: Map of the two villages of Belchite (Provincial Historic Archive of Zaragoza).
The venue was declared "Bien de Interés Cultural" (Heritage of Cultural Interest) in 2002 and as a result of that, a Project Action Plan in the old Belchite was drafted (Vidal 2014). It projects among other things, the consolidation and restoration of some of its buildings. In recent years, the restoration of three of these buildings has been carried out: the tower of the missing church of San Juan, known as "Torre del reloj" (2003) followed by the two main gates of the village which are known as "Arco de la Villa (2008) and "Arco de San Roque" (2010). Nowadays, the enclosure of the old Belchite is fenced allowing access to the public only with the guided tours organized by the tourist office in the village. There is a need to supplement these tours with other materials that can explain visually and didactically where the streets and major monuments can be found. Thanks to this appreciation, the virtual reconstruction project emerges as a great support to the promotion and dissemination of its architectural heritage.

\section{Methods}

This essay aims to be the beginning of a more ambitious project to be extended to cover the entire village. But this requires extensive research work of a team of professionals from different disciplines (Gutierrez et al. 2004; Gutierrez et al. 2008) like architects, historians, designers, etc., as well as the involvement of different administrations.

\subsection{Delineating the framework}

The choice of the convent of San Agustin for developing the virtual reconstruction is motivated by it being one of the most emblematic buildings of the enclosure with some historic and artistic values. In addition to this, there is the availability of abundant technical information, given the fact that monographs have been published, plans have been raised and lots of photographic material is kept (Vidal 2014; Baquero 1988).

This is a convent built in various stages between 1597 and 1716, and consists of a cloister from the renaissance period and a Baroque church, which facade and tower had certain influences of the Múdejar style characteristic of "el Bajo Aragón". The plan of the church is that of a Latin cross, with a hemispherical dome with lantern. It has a central aisle with a barrel vault with stained glasses and two heights lateral chapels with cross-vaulted. One of these chapels culminates with another hemispherical dome with a lantern, lower than the central chapel. Attached to the right wall is a chapel of late Baroque style that was added in the last phase of the construction of the building. The cloister had a square ground plant and it was attached to the left wall of the church. It was made of two floors of vaulted galleries that opened to the outside by semi-circular arches. The cells of the monks were distributed in two of its sides (Vidal 2014; Baquero 1988).

These days, all it remains in this building is the structure of the church as well as the facade and tower, with significant damage (Fig.3). There are only a few remains from the cover and rear and right side walls of the church. The same applies to the cloister, where the only thing left is its plot full of debris and two arcs that make up one corner of the gallery vaults on the first floor. 


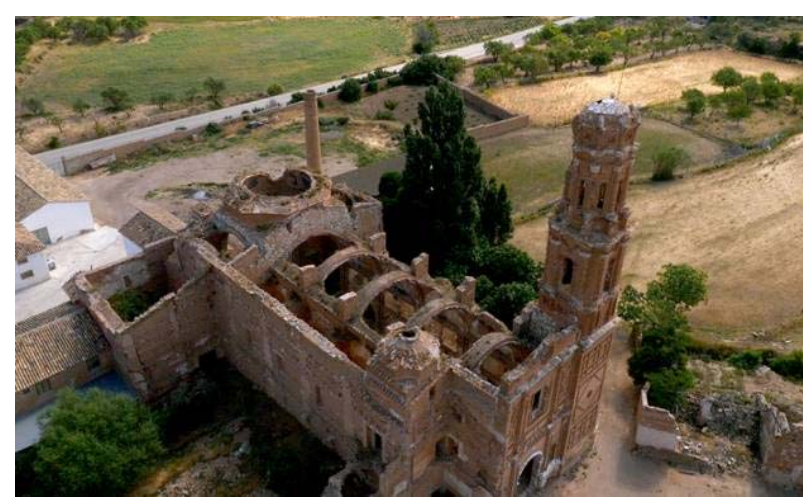

Figure 3: Aerial view of the convent of San Agustin (2015), in which you can see its current aspect.

\subsection{Election of the final product}

A virtual reconstruction serves as an element of exposure and dissemination of the reconstructed object. In the case of a building in ruins or already destroyed, virtual reconstruction provide support to research it and to raise different hypotheses in a graphical way. Among its many applications you can have the virtual reality (Scaglioni 2014), the possibility of hosting a virtual museum on a website (e.g. www.balawat.com and www.segobriga.org), all kinds of computer graphics and interactive tools that serve as content support. It can also be used as settings for video games or movies (e.g. www.entropystudio.net) as well as to create $3 \mathrm{D}$ printing models.

After analyzing all these applications, it was determined that the final product would be an informational video which serves as a comparison between the past (when the building was not in ruins yet) and the current time. This application allows showing the reconstruction on a very didactic and attractive way for the viewer, and allows easy webcasting, and/or display in exhibition halls. In order to show past, modeling techniques were chosen, while it was decided to alternate photogrammetry technique with real images of the building to represent the present moment. Starting from this decision, the video contents and modeling were planned adjusting this latter to the elements that were to appear in the audiovisual (Fig. 4).

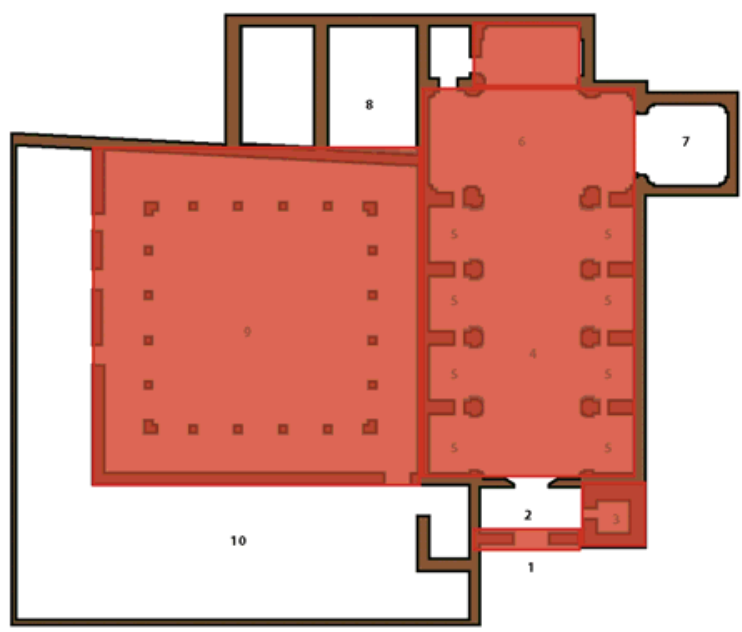

Figure 4: San Agustin's convent's floor, highlighting in red the elements that have been deeper analised in the modeling.
The proposed scenes for the video are as follows:

- Scene 1: Location of the building on the map of the village.

- Scene 2: General view of the building

- $\quad$ Scene 3: Tower view

- Scene 4: View of the facade

- Scene 5: View of the cloister

- Scene 6: View from inside the church

They stand out the most characteristic elements of the building and what the most architectural and artistic value is. In order to optimize resources, modeling assignments have focused especially on items that are displayed in the scenes.

\subsection{Modeling}

The previous information which was available for modeling was as follows

- $\quad$ Buildings plans (Vidal 2014; Baquero 1988)

- Pictures past and present (Cinca et al. 2008; Administration General Archive).

- Visits to the building

Taking as a reference the existing plans of the set, it has been built the building with SolidWorks, a 3D modeling software. For the making of the most damaged areas, visualization and analysis of old photographs have been necessary. Most of the consulted old photographs are dated after the war; from the 40s of the twentieth century approximately, in these you can see that the building still has its cover, and part of the cloister. The back of the presbytery and the domes had already been lost.

Modeling process consists on a sequence of operations trought the volume of the building is generated, as well as extrusions, lofts, sweeps, symmetries, pattern operations, etc. Some operations are shown in Figure 5.

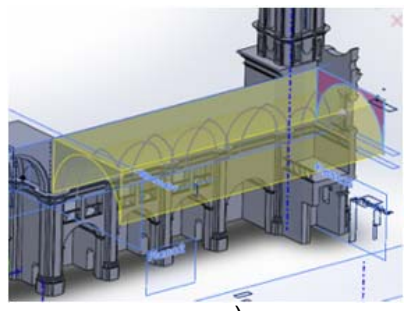

a)

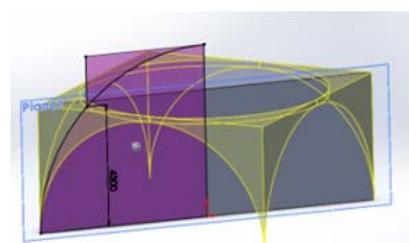

c)

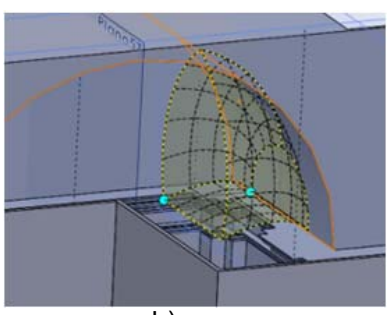

b)

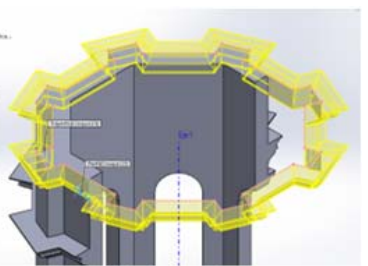

d)
Figure 5: Diferent modelling operations: a) Extrusion; b) Lofting; c) Revolved cut; d) Sweep.

As an example of the methodology used, the process of generating the 3D model of the cloister will be detailed. To this end remains visits were conducted in order to obtain information about them. It was noted that the lateral wall left of the church traces of the vaulted gallery 
on the first floor are preserved (Fig. 6), thanks to which the number of arches that had and its dimensions are known, reflected in existing plans (Vidal 2014). You can also appreciate the holes where the beams of the ceilings and floors were placed, thanks to which you can determine the height of the floors. It is then compared with the existing old photographs, which are after the war (from 1939 and 1940). In these pictures you can see the exterior details (Fig. 7), which are repeated modularly along the four facades, which assumes that they were equal because the cloister was square floor (Vidal 2014; Baquero 1988). In Figure 8 you can see the cloister's 3D reconstruction.

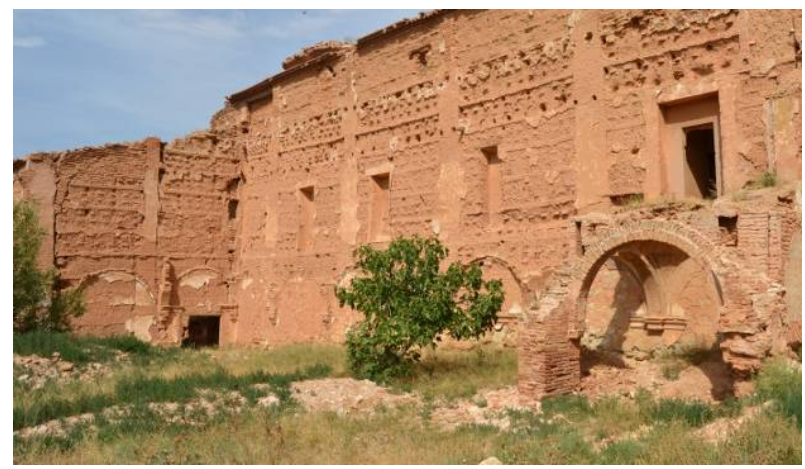

Figure 6: Cloister current aspect (2015). The remains of the arches of the vaulted gallery can be seen on the wall.

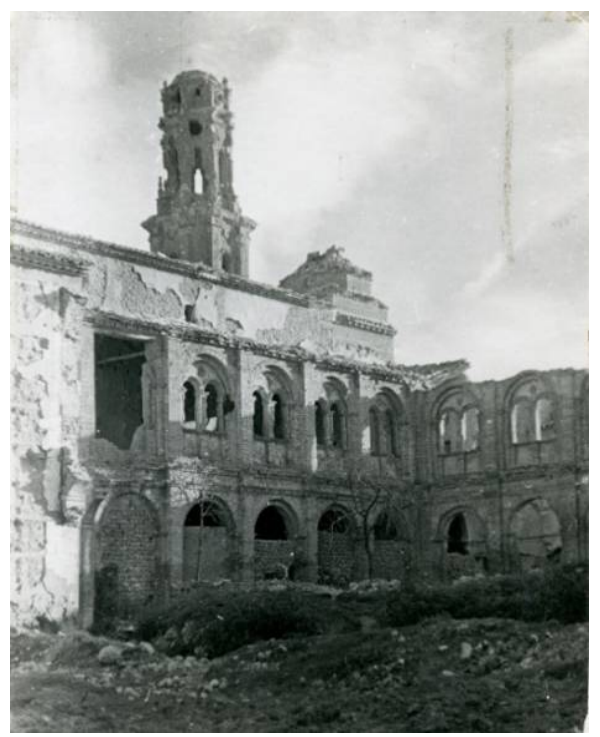

Figure 7: Cloister view in the 40s (Administration General Archive)

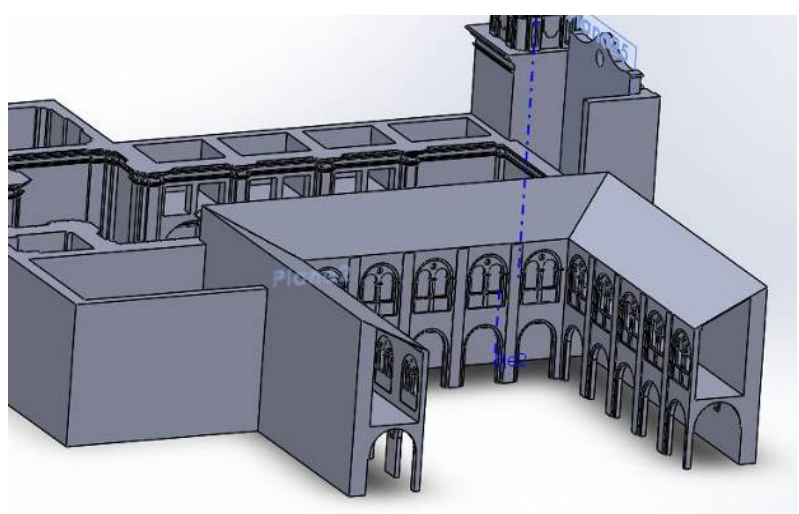

Figure 8: Cloister modelling process.

The final result of the total reconstruction shown in Figure 9 emphasizes the elements already lost.

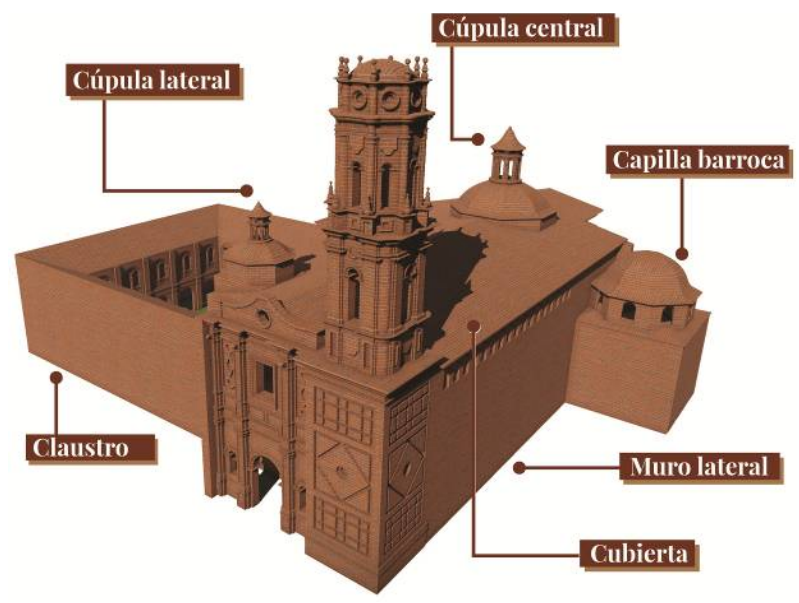

Figure 9: The end result of the reconstruction. They have highlighted the elements of the building that no longer exist today and therefore it has been necessary to go to old photographs in order to figure the hypothesis of reconstruction.

\subsection{Photogrammetry}

In addition to real images either coming from video or photograph, a way to show the current state of the building it is through the technique of photogrammetry. This means taking pictures all around the object being scanned (Figs. 10 and 11), and then process them with an appropriate software in order to generate the 3D model. In this project Autodesk 123D Catch has been the choosen software.

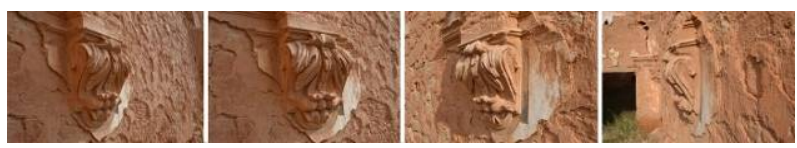

Figure 10: Detail of some of the photographs used to generate the photogrammetric model. 


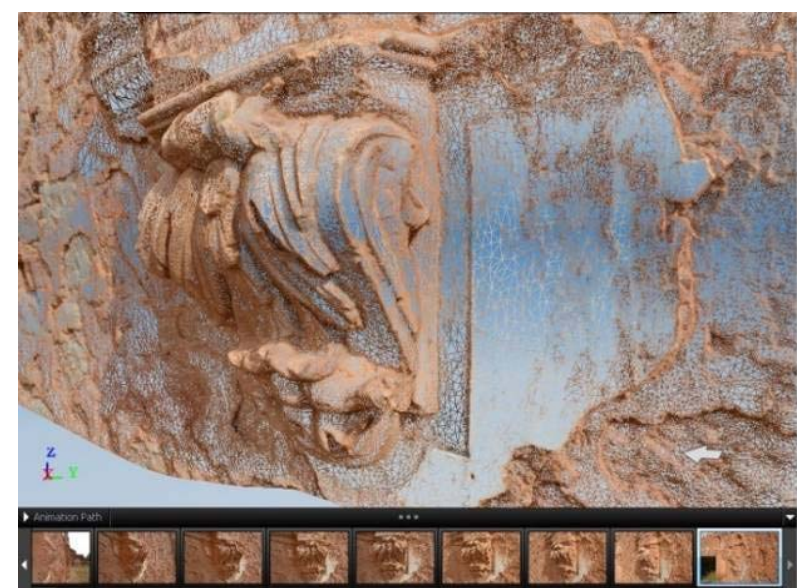

Figure 11: Photogrammetric model of the capitel in mesh view. In the bottom sequence are some of the nine pictures used for its realization.

In the present case, three tests were made with this technique, with elements of different sizes. They are the following, listed from smallest to largest: one of the capitals with which they began the vaults of the cloister (Fig. 11), corner arches that remains from the cloister (Fig. 12), the main facade next to the tower (Fig. 13).

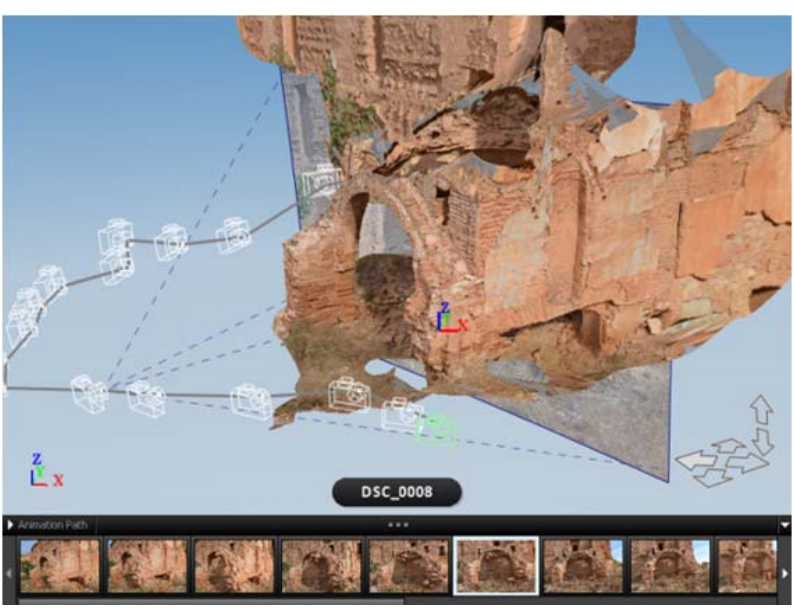

Figure 12: Photogrammetric model of the remains of arcs from the cloister made with 15 photographs. In the image it has been marked the different points were pictures have been taked from, which are shown on the bottom sequence.
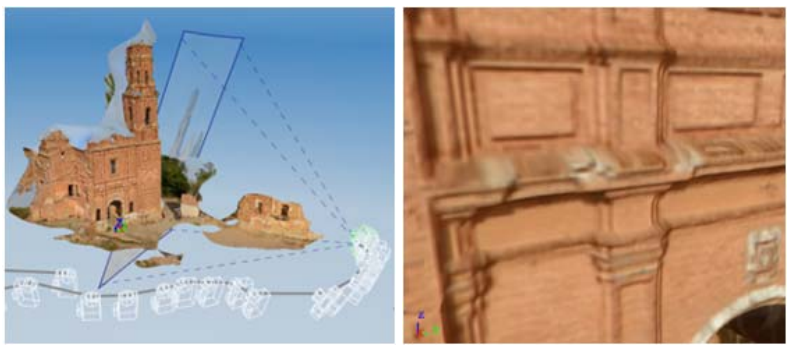

Figure 13: Left: Photogrammetric model of the church facade made with 21 photographs. Right: detail of the facade. Because the greater distance shooting photos this model is less accurate than the others.

It is noted that the smaller the scanned object was the greater was its precision; this is because the photographs are taken at a shorter distance so they have more definition. One of the advantages that photogrammetric models have is that not only they scan the object geometry but they also digitize the texture, giving the model greater realism.

\section{Results}

\subsection{Audiovisual production}

Finally we proceeded to the production of the audiovisual. It has some input materials which have served as the starting point to approach some of the scenes. It is as follows:

- A map of the town of 1920 (Spanish National Geographic Institute).

- Different drone recorded videos showing the ruins (Air Media 360, Belchite Tourism)

\subsubsection{Animation process}

Starting from a basic modeling, without details (Fig. 14), the ornamentation of the building emerges through an animation made by the SolidWorks Motion tool (Fig. 15). Ornamental elements have been divided and subsequently animated.

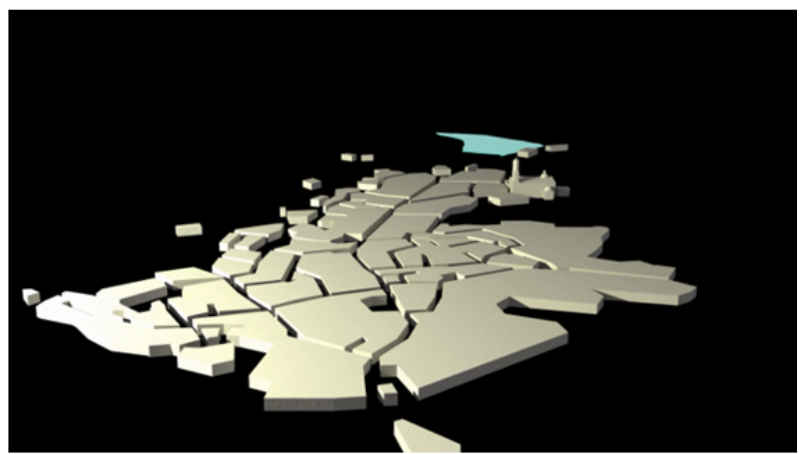

Figure 14: Extruded Map of the old Belchite. Emphasizes the church with a more detailed modeling.

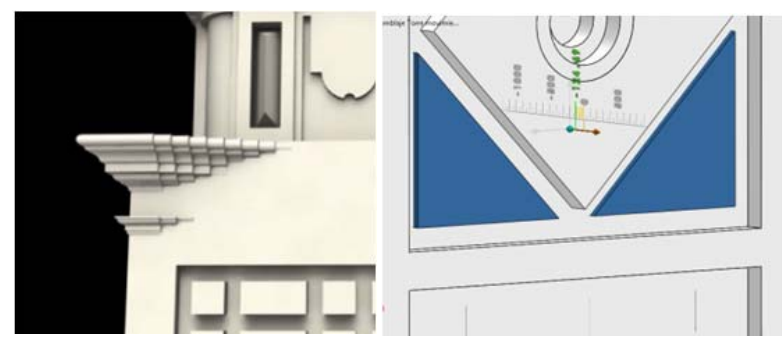

Figure 15: Ornamental elements animation process.

For other scenes it has been used 3D model with wireframe hidden lines removed view to be overlaid over the real image of the building (Fig. 16). Thereby the missing parts are displayed.

\subsubsection{Final result}

The final result is a video about 3 minutes long which alternates current images with images of the 3D model.

It begins with the map of the town (Fig. 14) that places the action in 1920, and then it moves to the place where the convent is located. By a transition between the 3D model and one of the videos, it then goes on to display the current status of the building. At the end of the video 
the image stops at a picture and it draws on the image the elements of the building that don't exist any longer in reality (Fig. 16).

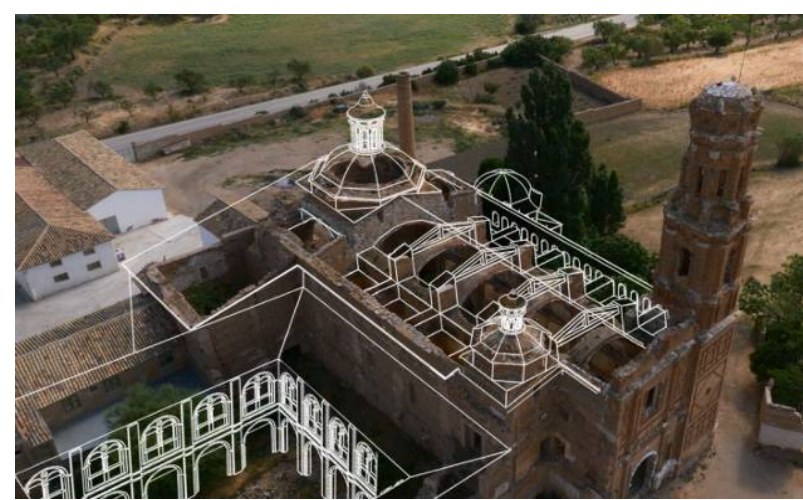

Figure 16: 3D model with wireframe view overlaid over the real image of the building.
The following scene show details of the tower, the facade and the cloister. The latter shows the photogrammetric model of the unique remains that are left from it. This 3D model merges with a picture of the current state on which the missing elements are drawn.

Finally another video of the rear of the building is shown, in which the camera enters the interior behind the remains of the dome. Image that overlaps with a rendering of the interior. In Figure 17 a series of frames of video are displayed, for your understanding.

Among the advantages of an audiovisual production is the fact that the distribution channel can be very wide, thanks to the Internet, to reach a larger audience and serve as advertising of the historic complex. It can also serve as a complement to a documentary, or even belong to the contents of a future center of interpretation.

The final video can be played on the following link: https://www.youtube.com/watch?v=NQYJI1IQwAE
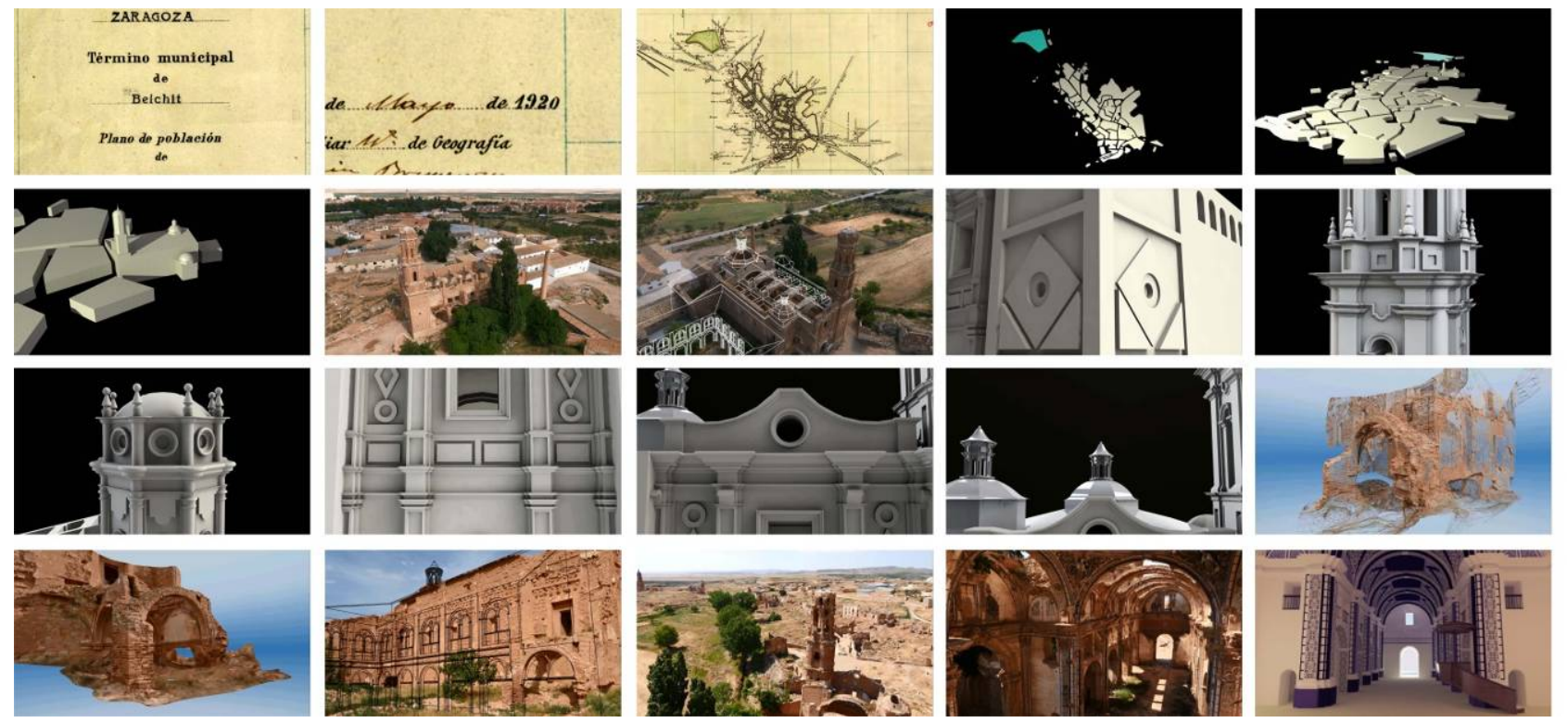

Figure 17: Selection of keyframes Video.

\subsection{Digital model applications}

The divulgative video is one of many applications that the 3D model resulting from this work can have. Listed below are some of the various applications that migh have:

- $\quad$ Generation of a model using a 3D printer (Fig. 18).

- Being part of a virtual and interactive museum that was housed in the network.

- Infographics and exhibition panels.

\subsection{Impact}

This work was presented in the exhibition "Old Belchite. Ruins of inspiration and creation..." held in December 2015 in the Belia exhibition hall in the new Belchite (Fig. 19). The audiovisual was projected and was well received by the audience.

\section{Conclusion}

As has been observed, a virtual reconstruction is a useful tool for the dissemination of the lost heritage. It would be interesting make the reconstruction of the whole village. The book "El viejo Belchite, la agonía de un pueblo" (Cinca et al. 2008) collects the largest collection of old photographs of the town coming from different files. Based on that book it could be said that there are photographs of most of the village (40s) but not from all. The biggest problem is that nowadays most of these buildings no longer exist, so no reference measurements. The reconstruction could be made based only on the photographs, and the dimensions of the streets. For this reason the result would be less accurate, although approximate and fulfill its function that would show to the viewer the lost heritage value. 


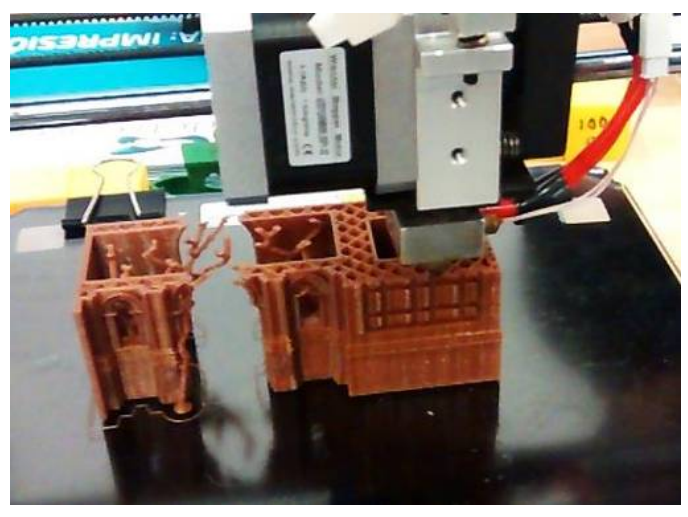

a)

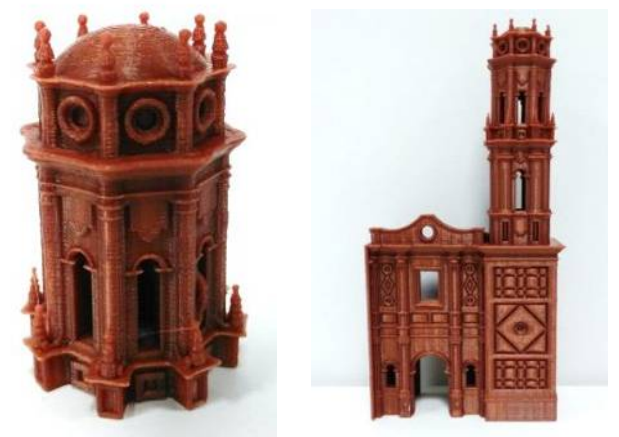

b)

Figure 18: Above: 3D printing process: a) first printed part of the tower finished; b) complete assembly of the facade.
In the case that the whole town was rebuilt, it would be interesting that the viewer could walk through it, either through a website or through an application of virtual reality. For this kind of reconstruction it would be appropriate that have a realistic look, therefore would be necessary to generate the textures of the materials of the buildings from photographs and with the help of image editing software. It should also be considered ways to interact with the propagation of light based on the laws of physics, such as the types of material, fog, dust, aerial perspective, etc. (Gutierrez et al. 2008). Thus the realism of the reconstruction is emphasized.
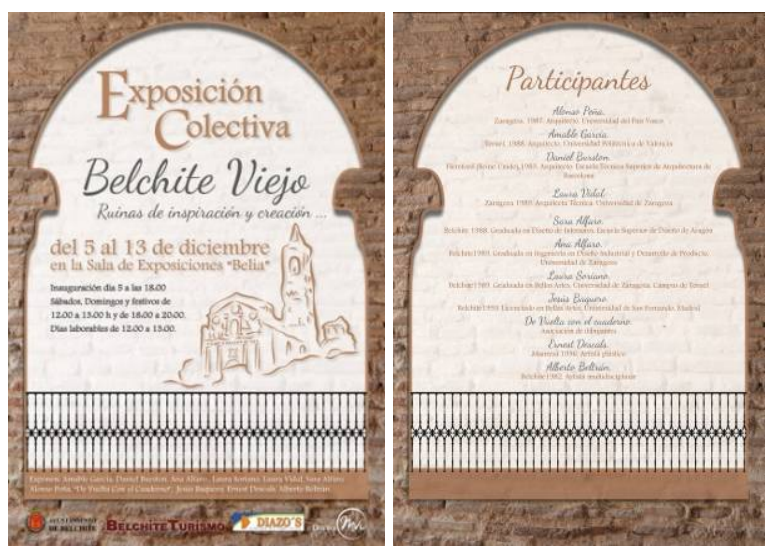

Figure 19: Group exhibition poster "Old Belchite. Ruins of inspiration and creation...".

\section{References}

BALAWAT, 2015. Balawat.com. Comunicación multimedia para la Arqueología [online] www.balawat.com/ [Consult: 12/07/2015].

BAQUERO, J., 1988. Inventario del patrimonio arquitectónico del Pueblo Viejo de Belchite (Zaragoza). Institución Fernando el Católico. ISBN:84-7820-019-3

CINCA, J., ALLANEGUI, G. and ARCHILLA, A.P, 2008. El Viejo Belchite, la agonía de un pueblo. Programa "Amarga Memoria". ISBN: 978-84-8380-085-0

FIAMMINGHI, S., BARTOLINI, G., DESKSPACE and SCAMPOLI, E., 2008. Firenze dall'età romana al Trecento [online] www.youtube.com/watch?v=nvJZHOS3VBO [Consult: 15/04/2016].

GUTIÉRREZ, D., SERÓN, F.J., MAGALLÓN, J.A., SOBREVIELA, E.J. and LATORRE, P., 2004. Archaeological and cultural heritage: bringing life to an unearthed Muslim suburb in an immersive environment. Journal of Cultural Heritage, 5 (2004), pp. 63-74. DOI: 10.1016/j.culher.2003.10.001

GUTIÉRREZ, D., SUNDSTEDT, V., GÓMEZ, F. and CHALMERS, A., 2008. Modeling light scattering for virtual heritage. ACM J. Comput. Cult. Herit. 1, 2, Article 8 (October 2008), 15 pages. DOI: 10.1145/1434763.1434765 http://doi.acm.org/10.1145/1434763.1434765

LABORATOIRE MAP du CNR (Marseille), 2014. L'Abbaye en animation 3D. http://abbayecuxa.com/index.php/presentation/ [Consult: 22/12/2014].

PERIPIMENO, M. and STRUFALDI, F., 2015. Piero di Cosimo e la Firenze del '500 [online] https://vimeo.com/132442094 [Consult: 20/10/2015].

SCAGLIONI, A., 2014. Zaragoza a lápiz (APP de realidad aumentada) [online] http://zgzalapiz.blogspot.com.es/p/appde-realidad-aumentada.html [Consult: 13/12/2014].

VIDAL, L., 2014. Estudio/análisis histórico-constructivo del convento de San Agustín del Pueblo Viejo de Belchite, Zaragoza. Universidad Politécnica de Cataluña 